\title{
Diallel mixed-model analysis of papaya fruit deformities
}

\author{
Deisy Lúcia Cardoso ${ }^{1}$ Marcelo Vivas ${ }^{2 *}$ Fernanda Oliveira Pinto $^{2}$ Alexandre Pio Viana ${ }^{2}$ \\ Antonio Teixeira do Amaral Júnior ${ }^{2}$ Messias Gonzaga Pereira ${ }^{2}$
}

${ }^{1}$ Universidade Anhanguera (UNIDERP), Unidade Agrárias, Avenida Alexandre Herculano, 1400, 79037280, Campo Grande (MS), Brasil. ${ }^{2}$ Laboratório de Melhoramento Genético Vegetal (LMGV), Centro de Ciências e Tecnologias Agropecuárias (CCTA), Universidade Estadual do Norte Fluminense Darcy Ribeiro (UENF), Av. Alberto Lamego, 2000, 28013-602, Campos dos Goytacazes, RJ, Brasil. E-mail: mrclvivas@hotmail.com. "Corresponding author.

\begin{abstract}
Changes in the shape of fruits from hermaphrodite flowers due to floral anomalies are quite common. The aim of this study was to estimate the effects of the general and specific combining ability on the proportions of normal and deformed (carpelloid and pentandric) papaya fruits in hermaphrodite plants using mixed models. The 'JS12-N', 'Waimanalo' and 'Golden' parents showed the potential to decrease the number of deformed fruits. In contrast, the 'Maradol x JS12-N', 'Maradol x Waimanalo', 'Maradol x Golden', 'JS12-N x JS12-4', 'JS12-N $x$ Sekati', 'JS12-N x Waimanalo', 'Waimanalo x JS12-N', 'Waimanalo x JS12-4', 'Waimanalo x Golden', 'Waimanalo x Sunrise Solo 72/12', 'Golden X Maradol', 'Golden x JS12-N', 'Golden x Sekati', 'Golden x Waimanalo' and 'São Mateus x JS12-N'hybrids have the potential to increase the number of marketable fruits while decreasing the number of carpelloid and pentandric fruits.

Key words: Carica papaya, carpelloidy, pentandry, REML/BLUP.
\end{abstract}

Análise dialélica via modelos mistos das deformidades em frutos de mamoeiro

RESUMO: Alterações na forma dos frutos originários de flores hermafroditas são bastante comuns. Estas alterações são provocadas por anomalias florais. Este trabalho teve como objetivo obter via modelos mistos estimativas de capacidade geral e especifica de combinação para proporção de frutos de mamoeiro normais e com deformidades: carpeloidia e pentandria, em plantas hermafroditas. Os genitores 'JS12-N', 'Waimanalo'e 'Golden'apresentam potencial para redução de frutos com deformidades. Os hibridos 'Maradol x JS12-N', 'Maradol x Waimanalo', 'Maradol x Golden', 'JS 12-N x JS12-4', 'JS 12-N x Sekati', 'JS 12-N x Waimanalo', 'Waimanalo x JS12-N', 'Waimanalo $x$ JS12-4', 'Waimanalo x Golden', 'Waimanalo x Sunrise Solo 72/12', 'Golden x Maradol', 'Golden x JS12-N', 'Golden x Sekati', 'Golden $x$ Waimanalo'e 'São Mateus x JS12-N' apresentaram potencial para aumento do número de frutos comerciais e redução de frutos carpelóides e pentândricos.

Palavras-chave: Carica papaya, carpeloidia, pentandria, REML/BLUP.

Brazil is one of the largest papaya (Carica papaya $\mathrm{L}$.) producers and exporters in the world, and its production is aimed at the domestic fresh fruit market as well as the fresh fruit export and industrial processing markets. This trade favors piriform fruits from hermaphrodite plants over spherical fruits from female plants. Therefore, female plants are removed from orchards as soon as they reach maturity, and planting is mostly restricted to hermaphrodite plants. Nevertheless, papaya fruits that are unmarketable due to their shape also result from hermaphrodite flowers, and this is caused by floral anomalies including carpelloidy and pentandry.

Breeders may use several resources and methods to meet the market demands for papaya cultivars with desirable agronomic characteristics. Directed crossing aims to recombine the existing genetic variability to select improved fruit shapes (BERNARDO \& BOHN, 2007), and diallel crossing methods, which provide data on the response of parents to each other and their hybrid combinations, have commonly been used in genetic breeding programs (CRUZ et al., 2012).

In papaya plants, mixed-model analysis remains underused, but its value in estimating genetic parameters and genotypic values in segregating populations to select papaya individuals based on desirable morphoagronomic traits have been reported in the literature (OLIVEIRA et al., 2012). The general combining ability estimates 
obtained by VIVAS et al. (2014) using mixed-model analysis were similar to estimates obtained using the method proposed by GRIFFING (1956).

Thus, the aim of this study was to identify the best parents and hybrid combinations to produce a higher proportion of normal fruits based on estimates of general and specific combining ability using linear mixed-model analysis. An experiment with a complete diallel design was performed at the Caliman Agrícola S/A company in Linhares, Espírito Santo (ES), Brazil. A total of 56 combinations (F1s and reciprocals) and their respective parents - four from the 'Formosa' group ('Maradol', 'JS12-N', 'JS12-4' and 'Sekati') and four from the 'Solo' group ('Waimanalo', 'Golden', 'Sunrise Solo 72-12' and 'São Mateus') - were evaluated in a completely randomized block design with four replicates, and each plot consisted of 10 plants (two rows with five plants each) with a spacing of $2.0 \times 1.8 \mathrm{~m}$. Treatments were spaced $3.6 \mathrm{~m}$ apart.

Three counts of all fruits with marketable characteristics and deformities (carpelloidy and pentandry) were performed at 170, 225 and 320 days after planting, and the mean of the three assessments was calculated as the percentage of fruits with marketable, carpelloid and pentandric characteristics. Percentages of each variable were used to obtain estimates of variance components in fruit shape (individual restricted maximum likelihood [REML] analysis), predicted additive genetic effect of parents and the specific combining ability of the crosses using model 36 in Selegen-REML/BLUP (best linear unbiased prediction) software (RESENDE, 2006). The predicted genetic values followed the statistical linear mixed models as follows: $\mathrm{y}=\mathrm{Xr}+\mathrm{Za}+\mathrm{Wf}+$ $\mathrm{e}$, where $\mathrm{y}$ is the data vector; $\mathrm{r}$ is the replicate effects vector (assumed fixed) added to the overall mean; $\mathrm{a}$ is the individual additive genetic effects vector (assumed random); $\mathrm{f}$ is the dominance effects vector (assumed random); and $\mathrm{e}$ is the error or residuals vector (random). Uppercase letters represent the incidence matrices of these effects.

The mixed-model equation used to estimate the fixed effects and predict the random effects resulting from the BLUP procedure follows (VIANA and RESENDE, 2014):

$$
\left[\begin{array}{l}
\hat{r} \\
\hat{a} \\
\hat{f}
\end{array}\right]=\left[\begin{array}{ccc}
X^{\prime} X & X^{\prime} Z & X^{\prime} W \\
Z^{\prime} X & Z^{\prime} Z+A^{-1} \lambda_{1} & Z^{\prime} W K \\
W^{\prime} X & W Z & W^{\prime} W K+A^{-1} \lambda_{2}
\end{array}\right]^{-1}\left[\begin{array}{c}
X^{\prime} y \\
Z^{\prime} y \\
W^{\prime} y
\end{array}\right] \text {, }
$$
where:

$K=\left(I+D A^{-1} \frac{\sigma_{d}^{2}}{\sigma_{a}^{2}}\right)$

$\lambda_{1}=\frac{\sigma_{a}^{2}}{\sigma_{g}^{2}}$

$\lambda_{2}=\frac{\sigma_{d}^{2}}{\sigma_{g}^{2}}$

The residual variance was lower than the genetic (additive and dominance) variance in the percentages of both marketable and carpelloid fruits. Unsurprisingly, the heritability values, in the narrow sense of these variables, were 0.56 and 0.67 , respectively (Table 1), and low heritability estimates and high residual variance were obtained for the percentage of pentandric fruits. Thus, marketable fruits are more easily produced, which should result from a reduction in the number of carpelloid fruits relative to pentandric fruits.

The estimates of general combining ability indicated that the 'Maradol', 'JS12-N', 'Waimanalo', 'Golden' and 'Sunrise Solo 72-12' parents have the potential to increase the proportion of marketable fruits and decrease the number of carpelloid fruits, whereas the 'JS12-N', 'Waimanalo', 'Golden' and 'São Mateus' parents reduced the number of pentandric fruits (Table 2). Furthermore, 'Maradol' and 'São Mateus' can potentially reduce the severity of powdery mildew in papaya leaves (VIVAS et al., 2012b), and 'Maradol' and 'São Mateus', together with 'JS12-N', also reduced the severity of phoma spot (VIVAS et al., 2013). The 'Golden', 'Sunrise

Table 1 - Restricted maximum likelihood (REML) estimates of variance components in the characteristics of papaya fruit shape and the resulting percentage of normal (marketable) fruits and the percentage of deformed (carpelloid or pentandric) fruits.

\begin{tabular}{lccc}
\hline Variance component & \%Marketable fruit & \%Carpelloid fruit & \%Pentandric fruit \\
\hline Additive genetic variance & 3.43 & 2.91 & 0.03 \\
Dominance genetic variance & 1.52 & 1.01 & 0.16 \\
Residual variance & 1.17 & 0.42 & 0.36 \\
Individual phenotypic variance & 6.12 & 0.34 & 0.56 \\
Heritability in the narrow sense & $0.56 \pm 0.19$ & 2.50 & $0.06 \pm 0.06$ \\
Overall mean of the experiment & 97.21 & & 0.29 \\
\hline
\end{tabular}


Table 2 - Estimates of the effects of general combining ability (predicted additive genetic effect) on the proportions of marketable, carpelloid and pentandric fruits from eight papaya parents.

\begin{tabular}{lccc}
\hline Genotypes & \%Marketable fruit & \%Carpelloid fruit & \%Pentandric fruit \\
\hline 'Maradol' & 1.36 & -1.44 & 0.01 \\
\hline 'JS12-N' & 1.47 & -1.19 & -0.12 \\
\hline 'JS12-4' & -3.40 & 3.11 & 0.15 \\
'Sekati' & -0.61 & 0.24 & 0.14 \\
'Waimanalo' & 1.64 & -1.52 & -0.06 \\
'Golden' & 0.69 & -0.56 & -0.05 \\
'Sunrise Solo 72-12' & 0.08 & -0.13 & 0.02 \\
São Mateus' & -1.22 & 1.49 & -0.08 \\
\hline
\end{tabular}

Solo 72-12' and 'São Mateus' genotypes have previously been reported to reduce the severity of black spot in papaya leaves and fruits (VIVAS et al., 2012a). Therefore, it is possible to produce genotypes with an increased number of normal fruits, a decreased number of deformed fruits and reduced disease severity.

Considering the $\hat{S}_{i j}$ estimates, those of
'Maradol', 'JS12-N', 'Sekati', 'Waimanalo', 'Golden' and 'São Mateus' were positive for the percentage of marketable fruits. These varieties showed negative $\hat{S}_{i i}$ estimates for the percentage of carpelloid fruits, and 'Maradol', 'JS12-N', 'Sekati', 'Waimanalo' and 'Golden' showed negative $\hat{S}_{i u}$ estimates for the percentage of pentandric fruits (Table 3). The highest divergence in the 'JS12-4' and 'Sekati' parents

Table 3 - Estimates of the effects of specific combining ability on the proportions of marketable, carpelloid and pentandric fruits from hybrids resulting from the crosses of eight papaya parents.

\begin{tabular}{|c|c|c|c|c|c|c|c|c|}
\hline \multirow{2}{*}{ Papaya parentes } & 1 & 2 & 3 & 4 & 5 & 6 & 7 & 8 \\
\hline & \multicolumn{8}{|c|}{-------------------------------------------------------------\%Marketable fruit------------------------------------------------------------ } \\
\hline 1 & 0.86 & 0.93 & 1.01 & 1.45 & 0.61 & 0.39 & -0.65 & -1.17 \\
\hline 2 & -0.78 & 0.82 & 0.30 & 1.16 & 0.18 & -1.61 & -0.02 & -1.24 \\
\hline 3 & -0.39 & -0.03 & -0.73 & 1.04 & -1.52 & -0.03 & 0.08 & -0.48 \\
\hline 4 & -3.63 & -0.06 & -0.77 & 1.36 & -2.56 & -1.09 & -0.33 & 1.04 \\
\hline 5 & -0.08 & 0.46 & 2.02 & -0.84 & 0.62 & 0.44 & 0.78 & -0.77 \\
\hline 6 & 0.75 & 0.30 & -0.37 & 0.23 & 0.74 & 0.57 & -0.24 & -0.12 \\
\hline 7 & 0.81 & -0.23 & -0.74 & 0.12 & 0.76 & -0.26 & -0.65 & 0.33 \\
\hline \multirow[t]{2}{*}{8} & 0.24 & 0.31 & -1.68 & 0.98 & 0.00 & 0.33 & 0.98 & 0.09 \\
\hline & \multicolumn{8}{|c|}{ - } \\
\hline 1 & -0.61 & -0.81 & -0.82 & -1.11 & -0.43 & -0.21 & 0.90 & 1.14 \\
\hline 2 & 0.91 & -0.82 & -0.10 & -0.94 & -0.12 & 1.64 & 0.14 & 1.21 \\
\hline 3 & -0.06 & -0.18 & 0.68 & -0.63 & 0.80 & 0.22 & -0.64 & 0.60 \\
\hline 4 & 1.85 & 0.15 & 0.42 & -1.11 & 1.79 & 1.15 & 0.50 & -0.86 \\
\hline 5 & 0.27 & -0.40 & -1.77 & 1.04 & -0.50 & -0.33 & -0.61 & 0.85 \\
\hline 6 & -0.57 & -0.29 & 0.14 & -0.07 & -0.62 & -0.51 & 0.24 & -0.33 \\
\hline 7 & -0.73 & -0.05 & 1.00 & -0.11 & -0.59 & 0.10 & 0.49 & -0.31 \\
\hline \multirow[t]{2}{*}{8} & -0.10 & -0.36 & 1.82 & -0.79 & 0.07 & -0.44 & -0.90 & -0.28 \\
\hline & \multicolumn{8}{|c|}{ 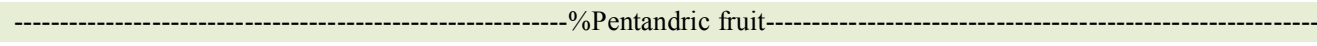 } \\
\hline 1 & -0.19 & -0.15 & -0.11 & -0.23 & -0.17 & -0.17 & -0.19 & 0.00 \\
\hline 2 & -0.15 & -0.11 & -0.19 & -0.19 & -0.13 & -0.09 & -0.15 & -0.08 \\
\hline 3 & 0.48 & 0.19 & 0.14 & -0.28 & 0.71 & -0.16 & 0.57 & -0.12 \\
\hline 4 & 1.77 & -0.06 & 0.45 & -0.09 & 0.79 & 0.00 & -0.07 & -0.16 \\
\hline 5 & -0.17 & -0.13 & -0.21 & -0.12 & -0.15 & -0.15 & -0.17 & -0.14 \\
\hline 6 & -0.17 & -0.09 & 0.24 & -0.10 & -0.15 & -0.10 & -0.02 & 0.33 \\
\hline 7 & -0.05 & 0.21 & -0.18 & 0.07 & -0.17 & 0.14 & 0.18 & -0.06 \\
\hline 8 & -0.16 & -0.07 & -0.13 & -0.17 & -0.14 & 0.03 & -0.12 & 0.06 \\
\hline
\end{tabular}

1 = 'Maradol'; 2 = ‘JS12-N'; 3 = 'JS12-4'; 4 = 'Sekati’; 5 = 'Waimanalo'; 6 = 'Golden'; 7 = SS72-12'; e, 8 = São Mateus'. 
may be explained by the largest $\hat{S}_{i i}$ distances for the percentage of marketable and carpelloid fruits between them.

In terms of the specific combining ability estimates for the three fruit characteristics, the following crosses exhibited positive values for the proportion of normal fruits and negative values for the proportions of carpelloid and pentandric fruits: between the 'Maradol' parent and the 'JS12-N', 'JS12-4', 'Sekati', 'Waimanalo' and 'Golden' parents; between the 'JS12-N' parent and the 'JS124', 'Sekati' and 'Waimanalo parents; between the 'JS12-4' parent and the 'Sekati' parent; between the 'Sekati' parent and the 'São Mateus' parent; between the 'Waimanalo' parent and the 'JS12-N', 'JS12-4', 'Golden' and 'Sunrise Solo 72/12' parents; between the 'Golden' parent and the 'Maradol', 'JS12-N', 'Sekati' and 'Waimanalo' parents; between the 'Sunrise Solo 72/12' parent and the 'Maradol', 'Sekati' and São Mateus' parents; and between the 'São Mateus' parent and the 'Maradol', 'JS12-N', 'Sekati' and 'Sunrise Solo 72/12' parents (Table 3). Thus, all of these crosses are considered promising for papaya breeding programs.

\section{REFERENCES}

BERNARDO, R.; BOHN, M.O. Plant breeding in times of change. Crop Science, v.47, p.S2-S3, 2007. Available from: <https:// www.crops.org/publications/cs/abstracts/47/Supplement_3/S2 ? access $=0 \&$ view $=$ pdf $>$. Accessed: Oct. 13,2014 . doi: $10 . \overline{2} 135 /$ cropsci2007.04.0001 edIPBS.

CRUZ, C.D. et al. Modelos biométricos aplicados ao melhoramento genético. Viçosa: UFV, 2012. 514p.

GRIFFING, B. Concept of general and specific combining ability in relation to diallel crossing systems. Australian Journal of Biological Sciences, v.9, p.462-493, 1956. Available from: <http:// www.publish.csiro.au/?act=view_file\&file_id=BI9560463.pdf $>$. Accessed: Jan. 30, 2014. doi: 10.1071/BI9560463.

OLIVEIRA, E.J. et al. Plant selection in F2 segregating populations of papaya from commercial hybrids. Crop Breeding and Applied Biotechnology, v.12, p.191-198, 2012. Available from: <http://www.scielo.br/scielo.php?pid=S198470332012000300005\&script $=$ sci_arttext $>$. Accessed: Jul. 14, 2014. doi: 10.1590/S1984-70332012000300005.

RESENDE, M.D.V. O software Selegen Reml/Blup. Campo Grande: Embrapa Gado de Corte, 2006. 299p.

VIANA, A.P.; RESENDE, M.D.V. Genética quantitativa aplicada no melhoramento de fruteiras. Rio de Janeiro: Interciência, 2014. 282p.

VIVAS, M. et al. Capacidade combinatória em mamoeiro para resistência a oídio. Bragantia, v.71, p.455-459, 2012b. Available from: $\quad<$ http://www.scielo.br/scielo.php?script $=$ sci_arttext\&pid=S0006-87052012000400001\&lng=pt\&nrm= 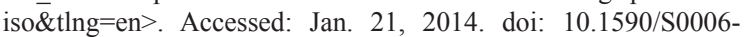 87052012000400001 .

VIVAS, M. et al. Capacidade Combinatória e heterose para resistência a pinta-preta em mamoeiro por meio de análise dialélica. Tropical Plant Pathology, v.37, p.326-332, 2012a. Available from: <http://www.scielo.br/scielo.php?script=sci_ arttext\&pid $=\mathrm{S} 1982-56762012000500004 \& 1 \mathrm{~g}=\mathrm{pt} \& \mathrm{nrm}=$ is o\&tlng=en>. Accessed: Jan. 20, 2014. doi: 10.1590/S198256762012000500004

VIVAS, M. et al. Análise dialélica em mamoeiro para resistência a mancha-de-phoma. Ciência Rural, v.43, p.945-950, 2013. Available from: $<$ http://www.scielo.br/scielo.php?script=sci arttext\&pid $=\mathrm{S} 0103-84782013000600001 \& \operatorname{lng}=\mathrm{pt} \& \mathrm{nrm}=$ is o\&tlng=en>. Accessed: Feb. 23, 2014. doi: 10.1590/S010384782013005000054

VIVAS, M. et al. Efficiency of circulant diallels via mixed models in the selection of papaya genotypes resistant to foliar fungal diseases. Genetics and Molecular Research, v.13, p. 4797 4804, 2014. Available from: <http://www.funpecrp.com.br/gmr/ 